\title{
Дія $2^{\prime}, 5^{\prime}$-триолігоаденілату та його епоксипохідного на репродукцію вірусу імунодефіциту людини та на активність зворотної транскриптази ретровірусів
} \author{
Л. В. Ткачук, І. О. Михайлопуло ${ }^{3}$, Г. Х. Мацука \\ Інститут молекулярної біології та генетики НАН України \\ Вул. Академіка Заболотноюо, 150, Київ, 03143, Україна

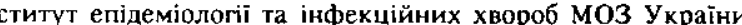 \\ Узвіз Протасів яр, 4, Київ, 03038, Україна \\ 2 \\ Вул. Васильківська, 45, Киї, 03022, Україа \\ 3 \\ Інститут біоорганічної хімії АН Беларусі \\ Вул. Жодінська, 5/2, Мінськ, 220067, Бєларусь
}

3. Ю. Ткачук, С. Л. Рибалко ${ }^{1}$, Л. І. Семерникова, В. В. Ткачук, М. П. Завелевич²,

\begin{abstract}
Досліджено дію 2',5'-триолігоаденілату (2',5'ApApA) та його епоксипохідного $\left(2^{\prime}, 5^{\prime}-\right.$ A2 $\left._{2}(\mathrm{RA} A)\right)$ на репродукцію вірусу імунодефіциту людини (ВIЛ-1). Показано, що 2',5'-олісоаденілати пригні'ують репродукцію вІЛ-1 у випадку їхньӧ попередньӧ інкубацї̈ з клітинами лімфобластоїдної лінї МТ-4. вивчено можливі механізми противірусної дї 2',5'-олігоаденілатів, а саме: проаналізовано інтерфероногенну дію цих препаратів. Показано, що 2',5'ApApA та 2',5'-A2(RAA) підвищують рівень інтерферону в клітинах у 2 і 4 рази відповідно порівняно з контролем. Виявлено інсібуючу дію 2',5'-олігоаденілатів на активність зворотної транскриптази ендо- $і$ екзогенних ретровірусів. Припускасться, що 2',5'-триолігоаденілат та його епоксипохідне можуть використовуватися у боротьбі з ВIл-інфекцісю.
\end{abstract}

Вступ. Відомо, що 2',5'-олігоаденілати (2-5А) відіграють основну роль у набутті клітиною стійкості до вірусів. Ключовими ферментами системи 2-5А 2-5А-синтетаза, активність якої залежить від наявності вірусної або клітинної дволанцюгової РНK (dsPHK), і рибонуклеаза L, активована 2-5A. Дослідження останніх років показали, що система 2-5А є перспективною в боротьбі проти ВІЛ-інфекції [1-4]. До останнього часу застосування 2-5А похідних для підсилення цієї системи здавалося обмеженим, головним чином, через низьку спе-

(C) 3. Ю. ТКАЧУК, С. Л. РИКАЛКО, Л. І. СЕМЕРНИКОВА B. B. ТКАЧУК, М. П. ЗАВЕЛЕВИЧ, $\Omega$. Т. ТКАЧУК,

1. О. МИХАดЛОГУЛО, Г. $Х$. МАЦУКА, 1999 цифічність РНКази L до вірусної РНK [5]. У зв'язку з цим розроблено два нових підходи, які забезпечують вибірковий антивірусний ефект 2-5А системи, принаймні, проти BIJI-1 інфекції. Перший підхід полягає у вжутрішньоклітинній імунізації 3 використанням кДНК 2-5А-синтетази, зв'язаної 3 елементом трансактивної реакції (відповіді) (TAR) BIJ, другий - пов'язаний 3 пригніченням ретровірусної активності зворотної транскриптази за допомогою аналогів 2-5A.

Метою даної роботи було вивчення дії $2^{\prime}, 5^{\prime}-$ олігоденілату та його похідного на репродукцію ВІЛ-1, іхню інтерфероногенну дію, а також впливу $2^{\prime}, 5^{\prime}$-олігоаденілатів на активність зворотної транскриптази екзо- та ендогенних ретровірусів. 
Матеріали і методи. В роботі використано «корові» $2^{\prime}, 5^{\prime}$-олігоадекілати: 2', $5^{\prime}$-АрАрА $\left(2^{\prime}, 5^{\prime}-\mathrm{A}_{3}\right)$ i $2^{\prime}, 5^{\prime}-\mathrm{A}_{2}\left({ }_{\mathrm{RA}} \mathrm{A}\right)\left(2^{\prime}, 5^{\prime}\right.$-епокси $\left.\mathrm{A}_{3}\right)$, синтезовані в Інституті біоорганічної хімії АН Бєларусі [6].

Визначення анти-ВIJI-активності. Для тестування анти-ВІЛ-активності $2^{\prime}, 5^{\prime}-\mathrm{A}_{3}$ та $2^{\prime}, 5^{\prime}$-епоксиА $\mathrm{A}_{3}$ використовували лімфобластоїдну лінію клітин МТ-4. ВIJ-1, птам В III, продукували в суспензійній культурі лімфоцитів, яку було отримано в Інституті ім. Івановського РАН (Москва). Клітини МT-4 вирощували на середовищі RPMI$1640 \quad 3 \quad 10 \%$ ембріональної сироватки і гентаміцином у дозі 100 од/мл. Клітини інфікували вірусом імунодефіциту людини в дозі 2 lg $\mathrm{ID}_{50}$. Здійснено дві серії дослідів. У першій - препарати в нетоксичній концентраціі $\left(10^{-4} \mathrm{M}\right)$ вносили в клітини одночасно з вірусом та інкубували протягом 6 діб $\left(37{ }^{\circ} \mathrm{C}\right.$, в атмосфері $\left.5 \% \mathrm{CO}_{2}\right)$. У культуральному середовищі визначали концентрацію експресивного антигена р24 ВІЛ та його інфекційний титр [7]. Як контроль використовували азидотимідин, який широко застосовується в практиці при лікуванні людей, уражених ВІЛ. Друга серія дослідів передбачала попередню інкубацію клітин 3 препаратами. Препарати $2^{\prime}, 5^{\prime}-\mathrm{A}_{3}$ та $2^{\prime}, 5^{\prime}$-епокси $\mathrm{A}_{3}$ вносили в концентрації $10^{-4} \mathrm{M}$ у суспензію клітин МТ-4 та інкубували ї протягом 24 год. Далі клітини інфікували ВІЛ-1 та інкубували протягом 6 діб при температурі $37{ }^{\circ} \mathrm{C}$ в атмосфері $5 \% \mathrm{CO}_{2}$. Потім у культуральному середовищі визначали концентрацію антигена р24 ВIЛ та його інфекційний титр [7].

Активність інтерферону визначали в культуральному середовищі методом пригнічення цитопатичної дії вірусу везикулярнопо стоматиту [8].

Визначення активності зворотної транскриптази ретровірусів. Об'єктом дослідження були ендогенний ретровірус типу $\mathrm{C}$, що продукується перевивними клітинами мишачої лімфоми ОН-1, та екзогенний ретровірус Молоні лейкозу мишей. Клітини ОН-1 вирощували на середовиці Ігла 3 глютаміном, $10 \%$-м вмістом телячої ембріональної сироватки та гентаміцину з розрахунку 100 од/мл середовища. Клітини вирощували протягом п'яти діб при тсмпературі $37^{\circ} \mathrm{C}$. Вірус, продукований цими клітинами, є типовим ретровірусом типу $\mathrm{C}$ iз щільністю віріона $1,16 \mathrm{r} / \mathrm{cm}^{3}$ у градієнті щільності цукрози. Вірус містить високомолекулярну PHK та зворотну транскриптазу. Джерелом вірусу було культуральне середовище, яке звільняли центрифугуванням при $6000 \mathrm{~g}(15 \mathrm{xв})$ від уламків клітин. Далі вірус осаджували протягом 1 год при $100000 \mathrm{~g}$ крізь подушку $20 \%$-ї цукрози. Осад суспендували в буфері (1/100 відносно об'єму культурального середовища): 50 мМ трис- $\mathrm{HCl}, \mathrm{pH} 7,8,60 \mathrm{MM} \mathrm{KCl}$ і 2 мМ дитіотреїтол.

Для репродукціі вірусу Молоні використовували культуру нормальних фібробластів мишей NIH 3T3. Iі вирощували на середовищі RPMI $310 \%-м$ вмістом ембріональної телячої сироватки та гентаміцину із розрахунку 100 од/мл середовища. Клітини пересівали через три доби $(1: 10)$ після обробки версеном 3 трипсином. Вірус лейкозу мишей Молоні одержували у вигляді $10 \%$-го фільтрату 3 гомогенату пухлин селезінки мишей лініі BALB/c, заражених вірусом Молоні. Фільтрат одержували 3 Інституту експериментальної онкології ім. Р. Є. Кавецького НАН України. Перед зараженням вірусом клітини NIH 3N3 обробляли ДЕАЕ-декстраном ( $50 \mathrm{MKг} / \mathrm{Mr})$ в ростовому середовищі без сироватки протягом 4 год. Клітини промивали ростовим середовищем без сироватки та покривали монотар клітин фільтратом гомогенату пухлин в об'ємі 0,5 мл протягом 1 год. Фільтрат одержували центрифугуванням гомогенату при $6000 \mathrm{~g}$. Надосадову рідину фільтрували через міліпоровий фільтр ( $d=0,22$ мкм). Клітини після інкубації 3 фільтратом промивали середовищем без сироватки, заливали підтримуючим середовищем та інкубували до появи вірусу. Наявність вірусу визначали по активності зворотної транскриптази. Потім клітини пересівали, як звичайно, декілька разів, культуральні середовища збирали для одержання очищеного вірусу. Останні освітлювали центрифугуванням $(6000 \mathrm{~g}, 30 \mathrm{Xв})$, далі ультрацентрифугували при $100000 \mathrm{~g}$ (1 год). На дно центрифужної пробірки наносили 2 мл $20 \%$-го розчину цукрози. Осад суспендували в буфері в співвідношенні $1 / 100$ до вихідного об'єму культурального середовища. Буфер містив трис- $\mathrm{HCl}-50 \mathrm{MM}, \mathrm{pH} 8,1, \mathrm{NaCl}-$ $40 \mathrm{mM}$, дитіотреїтол -2 мМ. Отриману суспензію використовували як вірусовмісний матеріал.

Активність зворотної транскриптази визначали [9] на матриці poly $(r A) \cdot d(p T)_{10}$ (полірибоаденілова кислота - дезокситимідинова кислота) («Calbiochem», США). Інкубаційна суміш в об'ємі 100 мкл містила 50 мМ трис-НС, pH 7,8, 60 мМ $\mathrm{KCl}, 2 \mathrm{мM}$ дитіотреїтол, $0,2 \mathrm{MM} \mathrm{MnCl}_{2}, 0,1 \%$ об'єму тритону $\mathrm{X}-100,0,02$ опт. од. поглинання при 260 нм на пробу матриці, 1 мКі $\mathrm{H}^{3} \mathrm{TTP}$ (метил- ${ }^{3}$ ) (тимідин 5'-трифосфатамонієва сіль) («Amersham», Велика Британія), питома активність $64 \mathrm{Ki} /$ ммоль та немічений тимідинтрифосфат («Calbiochem») в концентраціi $10^{-5} \mathrm{M}$, а також 50 мкл 100-кратного концентрату вірусної суспен3іi. До контрольної проби матрицю не вносили. Досліджувані препарати $2^{\prime}, 5^{\prime}$-олігоаденілатів: $2^{\prime}, 5^{\prime}$ $\mathrm{A}_{3}$ та $2^{\prime}, 5^{\prime}$-епокси $\mathrm{A}_{3}$ вносили в реакційну суміш у 
концентраціях $10^{-4}$ та $10^{-5}$ відповідно. Проби інкубували протягом 1 год при $37{ }^{\circ} \mathrm{C}$. По закінченні реакції до проби додавали 1 мл водного розчину БСА в концентрації $100 \mathrm{мкг/мл} \mathrm{та} \mathrm{ТХО} \mathrm{кислоту} \mathrm{до}$ кінцевої концентрації $10 \%$. Пробу наносили під вакуумом на мембранні фільтри. Синпор 3 діаметром пор 0,4 мкм, промивали $5 \%$-ю ТХО та фіксували $96 \%$-м спиртом, фільтри висушували та вміщували в сцинтиляційні флакони з сцинтилятором ЖС-107. Радіоактивність ТХО-нерозчинної фракції визначали на рідинному лічильнику «Intertechnique» (Франція).

Результати та обговорення. Результати дослідів із впливу $2^{\prime}, 5^{\prime}$-олігоденілатів на репродукцію (ВІЛ-1) показали, що при одночасному введенні препаратів у концентрації $10^{-4} \mathrm{M}$ та вірусу в культуру клітин суттєвого впливу на репродукцію вірусу не відбувається.

Результати дослідів 3 попереднім введенням $2^{\prime}, 5^{\prime}$-олігоаденілатів (за 24 год до внесення вірусу) показали, що препарати $2^{\prime}, 5^{\prime}-\mathrm{A}_{3}$ і $2^{\prime}, 5^{\prime}$-епокси $\mathrm{A}_{3}$ пригнічують інфекційність ВІЛ. Як видно 3 таблиці, інфекційний титр ВІЛ при попередній інкубації клітин з $2^{\prime}, 5^{\prime}-\mathrm{A}_{3}$ свідчить про пригнічення репродукції вірусу на $2 \mathrm{lg} \mathrm{ID}_{50}$, а при інкубації з $2^{\prime}, 5^{\prime}$-епокси $\mathrm{A}_{3}$ - на $1 \mathrm{lg} \mathrm{ID}_{50}$. Відомо, шо препарат $2^{\prime}, 5^{\prime}$-епоксиА $A_{3}$ є стійким до дії клітинних фосфодіестераз, у той час як $2^{\prime}, 5^{\prime}-A_{3}$ менш стійкий до дії ферменту [10]. Для вияснення механізму дії препаратів було проведено досліди на іхню інтерфероногенну активність, яку вивчали в експериментах на клітинах МТ-4 з попереднім введенням (за 24 год) препаратів $2^{\prime}, 5^{\prime}$-А 3 та $2^{\prime}, 5^{\prime}$-епокси $\mathrm{A}_{3}$ в концентрації $10^{-4} \mathrm{M}$ перед інфікуванням ВІЛ.

Вплив 2',5'-Aз та 2', 5'-A2(RAA) на рівень інтерферону та репродукцію ВЈЛ-І у культурі лімфобластойдної лінії клітин $M T-4$

\begin{tabular}{|c|c|c|c|c|c|c|c|}
\hline \multirow[b]{2}{*}{ Препарат } & \multirow{2}{*}{$\begin{array}{c}\text { Анти. } \\
\text { ген } \\
\text { p24, } \\
\text { A492 }\end{array}$} & \multicolumn{4}{|c|}{ Інфекційний титр } & \multirow{2}{*}{$\begin{array}{c}\text { Ig } \\
\text { ID50 }\end{array}$} & \multirow{2}{*}{$\begin{array}{l}\text { Рівень } \\
\text { інтер- } \\
\text { феро- } \\
\text { ну, } \\
\text { мO }\end{array}$} \\
\hline & & $10^{-1}$ & $10-2$ & $10^{-3}$ & $10^{-4}$ & & \\
\hline $2^{\prime}, 5^{\prime}-A_{3}$ & 1,473 & 1,410 & 0,654 & 0,130 & - & 2 & 80 \\
\hline $2^{\prime}, 5^{\prime}-\mathrm{A}_{2}\left(\mathrm{RA}_{\mathrm{A}} \mathrm{A}_{3}\right.$ & 1,520 & 1,376 & 0,836 & 0,230 & - & 3 & 160 \\
\hline $\begin{array}{l}\text { Азидо- } \\
\text { тимідин }\end{array}$ & 0,455 & 0,399 & 0,137 & - & - & 1 & - \\
\hline Контроль ВІЛ & 1,422 & 1,546 & 1,015 & 0,323 & 0,192 & 4 & 40 \\
\hline
\end{tabular}
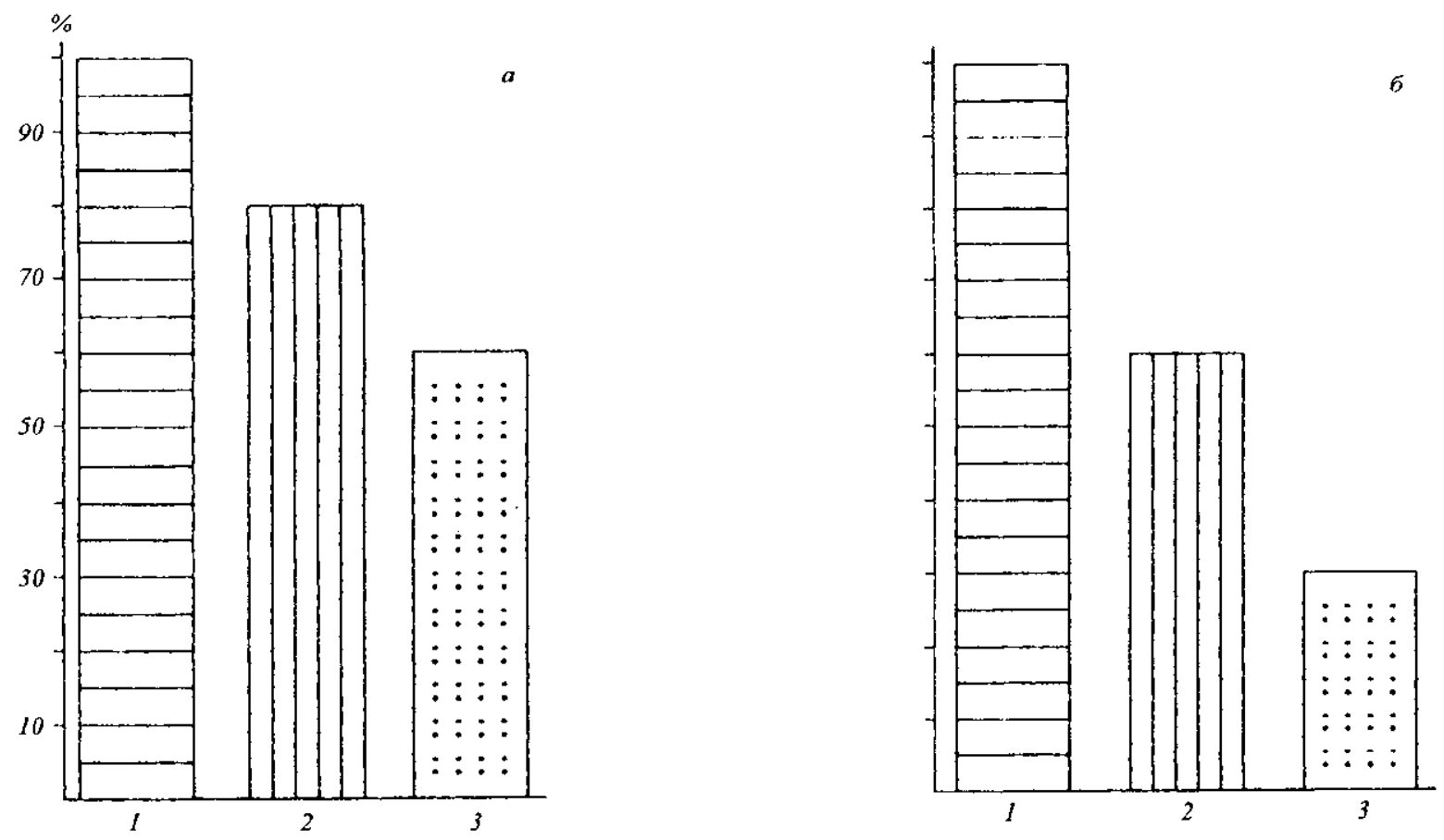

Рис. 1. Дія 2',5'-олігоденілатів на активність зворотноі транскриптази ендогенного ретровірусу типу С $(a, 6): 1-$ контроль; $2-$ концентрація $2^{\prime}, 5^{\prime}-\mathrm{A}_{3} 1 \cdot 10^{-5} \mathrm{M}\left(\right.$ a) i $1 \cdot 10^{-4} \mathrm{M}\left(\right.$ () $; 3-2^{\prime}, 5^{\prime}$-епокси $\mathrm{A}_{3}-1 \cdot 10^{-5} \mathrm{M}\left(\right.$ a) $\mathrm{i} 1 \cdot 10^{-4} \mathrm{M}(6)$ 
Було показано, щщо в зразках, оброблених препаратом, значно збільшується синтез інтерферону порівняно з контролем. Із даних габлиці випливає, що при обробці клітин препаратом $2^{\prime}, 5^{\prime}-\mathrm{A}_{3}$ кількість інтерферону вища в 2 рази порівняно 3 контролем. Препарат 2',5'-епоксиА $\mathrm{A}_{3}$ підвищує рівень інтерферону в 4 рази. Ще одним із можливих пояснень противірусної діі щих речовин відносно ВІЛ-1 може бути вплив 2',5'-олігоаденілатів на активність зворотної транскриптази ретровірусів. Для цього вивчали дію $2^{\prime}, 5^{\prime}$-оліго $A_{3}$ на активність зворотної транскриптази ендо- та екзогенних ретровірусів.

Отримані результати свідчать, що препарат $2^{\prime}, 5^{\prime}-\mathrm{A}_{3}$ в концентрації $10^{-5} \mathrm{M}$ пригнічує активність зворотної транскриптази ендогенного ретровірусу типу $\mathrm{C}$ на $20 \%$, а препарат $2^{\prime}, 5^{\prime}$-епокси $\mathrm{A}_{3}$ у тій же концентрації - на $41 \%$ (рис. $1, a$ ). Збілышення концентрації препаратів до $10^{-4} \mathrm{M}$ знижує активність ферменту, у випадку $2^{\prime}, 5^{\prime}-\mathrm{A}_{3}$ на $42 \%$, $2^{\prime}, 5^{\prime}$-епокси $\mathrm{A}_{3}$ - на $68 \%$ (рис. 1, б).

Експерименти, проведені із зворотною транскриптазою екзогенного вірусу Молоні лейкозу мишей, хакож показали інгібуючу дію досліджуваних препаратів. Препарат $2^{\prime}, 5^{\prime}-\mathrm{A}_{3}$ в концентрації $10^{-5} \mathrm{M}$ пригнічує активність ферменту на $25 \%$, а препа- рат $2^{\prime}, 5^{\prime}$-епокси $\mathrm{A}_{3}$ - на $57 \%$ (рис. 2, а). Збільшення концентрації препаратів до $10^{-4} \mathrm{M}$ посилило дію $2^{\prime}, 5^{\prime}-\mathrm{A}_{3}$ до $41 \%$, а 2',5'-епоксиА $\mathrm{A}_{3}$ - до $71 \%$ (рис. 2, б). Тахим чином, з'ясовано, що дефосфорильований «кор» $2^{\prime}, 5^{\prime}$-оліго $\mathrm{A}_{3}$, а також його епоксипохідне пригнічують активність зворотної транскриптази обох вірусів, але епоксипохідне має значно більшу інгібуючу дію. Виявлено концентраційну залежність даного ефекту.

Слід відмітити, що дія досліджуваних препаратів на зворотну транскриптазу ендо- та екзогенного ретровірусів майже однакова. 3 літератури відомо, що кордиципінові аналоги 2',5'-олігоаденілатів також пригнічують активність зворотної транскриптази різною мірою-залежно від концентрації та хімічної будови препаратів [11].

Вивчено кінетику інгібування зворотної транскриптази 2-5A [8]. Кінетичне пригнічення було змішаного типу, де 2-5A не жорстко конкурентне 3 dTTP. Іншими авторами було показано, що 2-5А та іхні похідні $\epsilon$ неконхурентними інгібіторами утворення комплексу: праймер (HIV) - зворотна транскриптаза [12]. Механізм та специфічність пригнічуючої діï 2-5А та його похідних залежали від модифікацій в рибозильній частині молекули, довжини ланцюжка, ступеню 5 '-фосфорилювання.
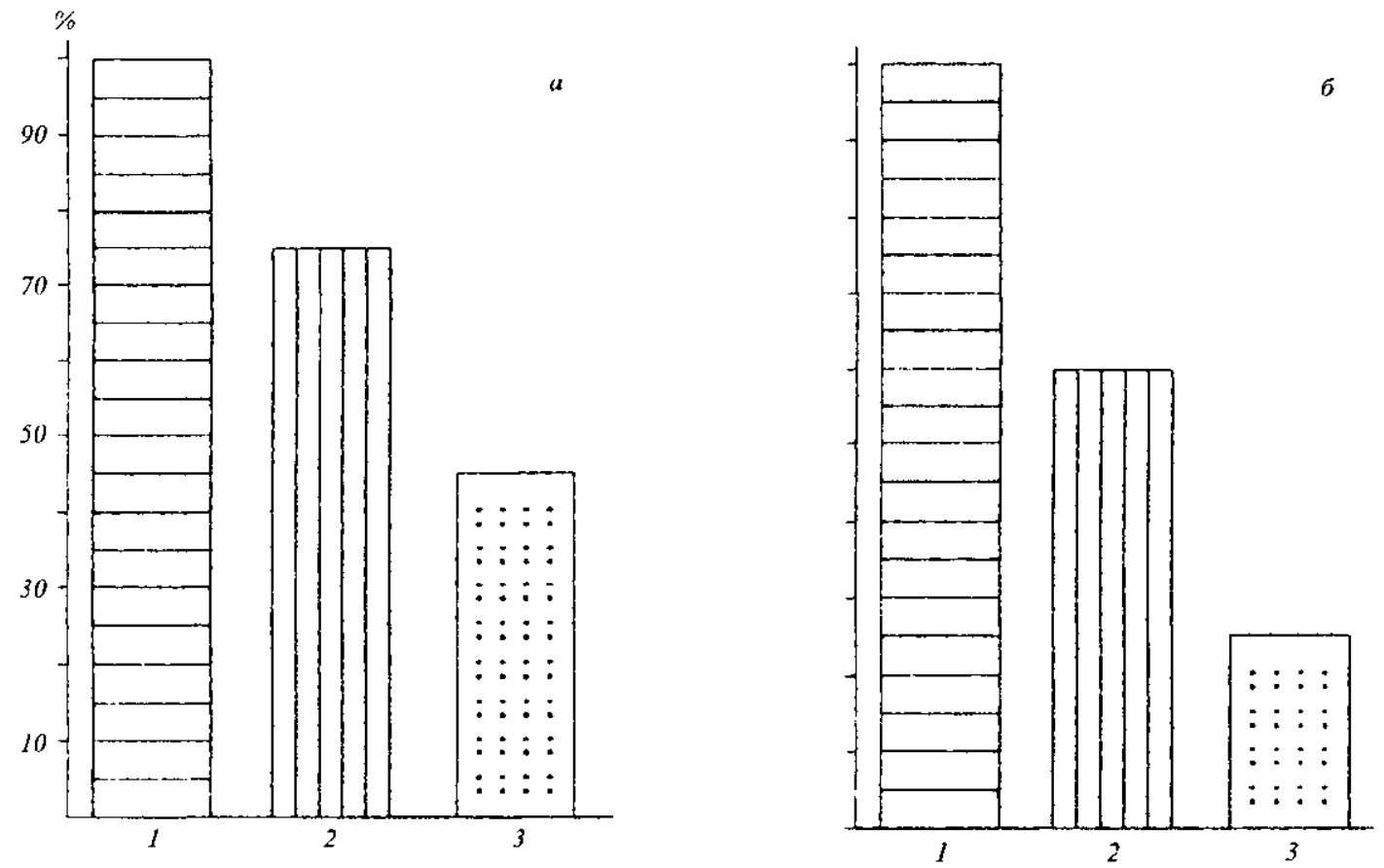

Рис. 2. Ція 2',5'-олігоаденілатів на активність зворотної транскриптази ендогенного ретровірусу Молоні $(a, 6): 1-$ контроль; $2-$ концентрація $2^{\prime}, 5^{\prime}-\mathrm{A}_{3} 1 \cdot 10^{-5} \mathrm{M}(a)$ i $1 \cdot 10^{-4} \mathrm{M}(6) ; 3-2^{\prime}, 5^{\prime}$-епокскА $3-1 \cdot 10^{-5} \mathrm{M}\left(\right.$ a) i $1 \cdot 10^{-4} \mathrm{M}(6)$ 
Це пригнічення $\epsilon$ специфічним для 2',5'-міжнуклеотидного зв'язку, і $2^{\prime}, 5^{\prime}$-похідні не мали інгібуючої активності.

В усіх випадках пригнічення праймер ВІЛ-1 транскриптазного комплексу показало перевагу $5^{\prime}-$ трифосфатної частини. Нефосфорильовані похідні не були інгібіторами зворотної транскриптази. Ці результати не узгоджуються 3 нашими даними, які показали, що дефосфорильований «кор» $2^{\prime}, 5^{\prime}$-олігоаденілат та його епоксипохідне $\epsilon$ інгібіторами зворотної транскриптази ретровірусів. Таким чином, противірусна дія досліджуваних препаратів відносно BLJ-1 може пояснюватися також пригніченням активності зворотної транскриптази.

Оцінюючи отримані результати, можна зробити припущення стосовно того, що 2',5'-оліго-А можуть бути перспективними у боротьбі зі СНІДом та супутніми вірусними інфекціями.

3. Ю. Ткачук, С. Л. Рыбалко, Л. И. Семерникова, В. В. Ткачук, М. П. Завелеви', Л. В. Ткачук, И. А. Михайлопуло, r. Х. Маиука

Дейстиие $2^{\prime}, 5^{\prime}$-триолигоаденилата и его эпоксипроизводного на репродукцию вируса иммунодефицита человека и на активность обратной транскриптазы ретровирусов

Резюме

Исследовано действие $2^{\prime}, 5^{\prime}$-триолисоаденилата $\left(2^{\prime}, 5^{\prime}\right.$ АрАрА) и его эпоксипроизводного $\left(2^{\prime}, 5^{\prime}-A_{2}\right)(\mathrm{RA} A)$ на репродукцию вируса иммунодефицита человека (ВИЧ-I). Показано, что 2',5'-олигоаденилаты угнетакт репродукцино вИч-1 в случае их предварительной инкубации с клетками лимфобластоидной линии МТ-4. Изунали возможные механизмы противовирусного действия 2',5'-опигоаденитатов, а именно: интерфероногенное действие этих препаратов. Показано, что 2',5' АрАрА и 2',5'$A_{2}\left({ }_{\mathrm{RA}}\right.$ A) увеличивакт количество интерферона в клетках в 2 и 4 раза соответственно по сравнению с контролем. Показано инсибирующее действие 2',5'-триолигоаденилатов на активность обратной транскриптазы эндо- и экзогенных ретровирусов. Предполагается, что 2',5'-триолигоаденилат и его эпоксипроизооное могут быть использованы в борьбе против ВИЧ-инфекции.

Z. Yu. Tkachuk, S. L. Rybalko, L. I. Semernikova, V. V. Tkachuk, M. P. Zavelevich, L. V. Tkachuk, I. O. Mikhailopulo,

G. Kh. Matsuka

The effect of trimeric $2,5^{\prime}$-oligoadenylic acid and its epoxyderivative on the human immunodeficiency virus reproduction and retroviruses reverse transcriptase activity

Summary

The study of the effect of trimeric 2',5'-oligoadenylic acid $\left(2^{\prime}, 5^{\prime} A p A p A\right)$ and its epoxyderivative $\left(2^{\prime}, 5^{\prime}-A_{2}\left(\mathrm{RA}^{A}\right)\right)$ on both human immunodeficiency virus (HIV-I) reproduction and retroviruses reverse transcriptase activity was conducted. $2^{\prime}, 5^{\prime}$-oligoadenylates were shown to suppress $H I V-I$ reproduction in case of their pre-incubation with the lymphoblastoid cells of $M T-4$ line. The possible mechanisms of antivirial action of $2^{\prime}, 5^{\prime}$-oligoadenylates were under investigation, in particular, the interferonogenic effect of the substances was examined. 2',5'ApApA and $2^{\prime}, 5^{\prime}-A_{2}\left(\mathrm{RA}^{\prime} A\right)$ were shown to increase amounts of interferon in cells two and four-fold respectively compared to control. The inhibitory effect of $2^{\prime}, 5$ ' oligoadenylates on activity of endogenous and exogenous retroviruses reverse transcriptase was demonstrated. The trimeric 2',5'-oligoadenylic acid and its epoxyderivative may be used against $H I V$ infection.

\section{СПИСОК ЛІТРАТУРИ}

1. Muller W. E., Schrodeer H. C. Alteration of (2'-5')oligoadenylatee metabolism and ribonuclease $\mathrm{I}$ activity in $\mathrm{H}-9$ cells by HIV // Int. Conf. AIDS. $-1989, \ldots$ P, 667

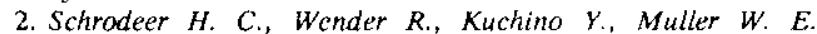
Modulation of nuclear matrix-associated $2^{\prime}, 5^{\prime}$-oligoadenylate metabolism and ribonuclease $L$ activity in 49 -cells by human immunodeficiency virus $/ /$ J. Biol. Chem.-1989.-264, N 10. -P. 5669 - 5673 .

3. Ueda M., Higasa S., Suehiro A., Kakishita E. Evaluation of immuno-status in HIV disease using serum $2^{\prime}, 5^{\prime}$-oligoadenylate synthetase activity // Int. Conf. AIDS. - $994 .-10, \mathrm{~N} 1 .-$ P. 158 .

4. Schroder H. C., Kelve M., Muller $W, E$. The 2-5A system and HIV infection // Progr. Mol and Subcell. Biol. -1994.-14.P. $176-197$.

5. Schroder H. C., Suhadolnik R. J., Pfleider W., Charubala R., Muller $W . E .\left(2^{\prime}, 5^{\prime}\right)$-oligoadenylate and intracellular immunity against retrovirus infection $/ /$ Int. J. Biochem.-1992.-24, N 1.-P. $56-63$.

6. Mikhailopulo I. A., Baran E. A., Tkachuk L. V. Synthesis and use in kidney transplantations in rabbits and monkeys of $\left(2^{\prime}, 5^{\prime}\right)$ oligoadenylate trimers modified at the $2^{\prime}$-terminus $/ /$ 4 th Int. symp. on Molecular aspects of chemotherapy $(23-25$ June, 1993, Gdansk).-Gdansk, 1993.-P. 61.

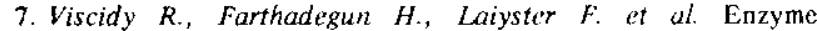
immunoassay for detection of human immunodeficiency virus antigen in cell cultures $/ / \mathrm{J}$. Clin. Micro.-1988.-26.P. $453-458$

8. Соловьев В. Д., Пектемиров Т. А. Интерфероны в теории и практике медицины.-М.: Медицина, 1981.-С. 85-90.

9. Liu $D$. K. Owens $G$. F. Inhibition of viral reverse transcriptase by $2^{\prime}, 5^{\prime}$-oiligoadenylates // łiochem. and Biophys. Res. Communs. $-1987 .-145, \mathrm{~N} 1 .-\mathrm{P} .219-297$.

10. Козлов $A . B$, Ткачук 3. Ю. Изучение устойчивости различньх аналотов $2^{\prime}, 5^{\prime}$-олитоаденилатов к действию фосфодиэстераз // Биополимеры и клетка.-1994,-10, № 1.C. $47-52$

11. Montefiori D. C., Sobol R. W., Li Shi Wu, Reichenbach N. I. Phosphorothioate and cordycepin analogues of $2^{\prime}, 5^{\prime}$-oligoadenylate: Inhibition of human immunodeficiency virus type $l$ reverse transcriptase and infection in vitro // Proc. Nat. Acad Sci. USA. -1989.-86.-P. $7191-7194$.

12. Sobol R. W., Fisheer M I., Reichenbach N. L., Kumar A., Beard W. A., Wilson S. H., Charubala R., Pfleiderer W., Suhadolnik $R$. J. HIV-reverse transcriptase: inhibition by 2',5'-oligoadenylates // Biochemistry. - $1993,-32, \mathrm{~N} 45 .-$ P. $12112-12118$. 